\title{
Analysis of Purchasing Markets in the Region of Asia
}

\author{
Yangyan Shi $\mathrm{a}^{*}$ \\ a School of Economics and Management, Shanxi University, Shanxi 030006, China. \\ ${ }^{*}$ Corresponding author's email address: ys102@hotmail.com
}

\begin{abstract}
A R T I C L E I N F O
Received: 14-09-2015

Accepted: 28-12-2015

Available online: 01-05-2016

Keywords:

Asia,

International sourcing,

Market research,

Purchasing.

\section{A B S T R A C T}

Due to the financial crisis 2008, many countries have faced the challenges from the economic downwards. There are many economic entities emerging from the region of Asia. Many foreign companies focus on exploring the Asian markets, due to low labor cost, cheap raw materials, and international transportation hub. This paper mainly examines purchasing markets in the region of Asia. Analyzing the economic outlook and business environment reveals the current market situation in the region of Asia. In addition, this paper highlights the key industries for each Asian country, which help international firms understand the features of industries in each country. A summary of popular exports products is also listed. The contribution of this paper is to give a comprehensive understanding overall of purchasing markets in the region of Asia.
\end{abstract}

JEL Classification:

This is an open access article under the terms of the Creative Commons Attribution License 4.0, which allows use, distribution and reproduction in any medium, provided the original work is properly cited.

DOI: http://dx.doi.org/10.18533/job.v1i3.4

ISSN: 2380-4041 (Print), 2380-405X (Online)

\subsection{Introduction}

As an emerging market, Asia still has higher growth characteristics and greater profitability than developed countries. The economy of Asia has significantly influenced the world economy. Due to the current financial crisis, each Asian country's economy presents different characteristics.

The advantage of People Republic of China (China) is that it keeps a low and stable inflationary environment and a secure external position. India has relatively high foreign currency reserves and low foreign debt stock. The future growth of Japan economy will depend on demand from the US and China. The trade-dependent economy for Singapore still relies on demand for electronic products. The principal weakness for Thailand is the poor quality of government expenditure. The economy of Taiwan depends on exports from a single sector (electronics). Pakistan has a high current account deficit and thin foreign exchange reserves. Indonesia's economic risk is constrained by currency validity and banking weaknesses. The uncertainty of government expenditure may drag down Malaysia's economy in a long term. The Philippines still face a number of political weaknesses, such lack of transparency and regulatory inconsistency, which will undermine the growth potential of its economy. The economy of South Korea is easily influenced by the global economy. Vietnam faces the long-term fiscal deficits.

From the business environment perspective, Singapore is in the top position in Asia. It continues to attract more foreign investment into the country. China has a number of obstacles for foreign investors wishing to do business in the country although it has a large supply of cheap labour and a rapid growing economy. Bureaucracy and legal framework are major concerns to foreign investors. Thailand encourages infrastructure planning to help 
businesses. The Cross-trait relations with Mainland of China have helped Taiwan transform itself into a key region logistics and financial hub. Pakistan and Indonesia face underinvestment into their infrastructures. Malaysia and the Philippines need to address the political corruption in order to attract more foreign investment. South Korea has more emerging business opportunities due to the standard of corporate governance has improved. Vietnam has more opportunities of transfer of high-tech skills and know-how.

Overall, Singapore remains an important hub for Research and development of electronic products and electronic manufacturing services. As China's leading role in world manufacturing continues, lower labour costs will be still more attractive for foreign investors. The grocery of Japan is projected to operate loss-making and price-cutting strategies during the economic downturn. Garments in India are one of main products for export. Thailand maintains a key hub for manufacturing electrical products. Taiwan has a significant advantage for high-tech products. Food and drink industry in Pakistan is a fast growing industry. Labour-intensive manufacturers are quite common in Indonesia and the Philippines. There are many small and medium-sized textiles and clothing manufacturers in Malaysia. The electronic industry is quite famous in South Korea, and Vietnam mainly exports crops, rice and coffee.

This report mainly analyses Asia's economic environment, business environment and key industries. The economic environment section describes the economic risk ratings for each Asian country. The business environment section states business risk ratings based on information of infrastructure and market orientation. The industry section lists some export products for each Asian country based on the outcome of survey conducted by Alibaba.com, which is one of the largest Business-to-Business companies in the globe.

\subsection{Economic outlook}

This section primarily describes the economies of the Asian countries. The two tables (table 1 and 2) show the short-term/long-term risk ratings for Asian countries based on the data offered by Business Monitor International (BMI). The higher scores represent that these countries have lower economic risk. Both tables also indicate the future economic trend for the Asian countries (normal, positive or negative trend).

Singapore's dependence on foreign trade contributes to the growth of its economy. Government policies strongly support its economic foundation. The Singapore's economy is more stable since its score is 83.3. The result for the long-term period is a score of 78.6 .

China has an impressive overall score of 92.1. The low and stable inflationary environment and secure external position has pushed the development of China's economy. The country places at No. 1 in the short term period, and also performs well in the long-term economic risk.

The short-term and long-term scores of Japan are 64.0 and 56.4 respectively, which they are not shown in the tables. Its scores are higher than the average scores of most other developed countries, such the United States, the United Kingdom, and German (53.9 for short-term and 51.8 for long-term). The future growth of Japan economy will be still weak.

Taiwan has the short-term score of 72.9, with the principal shortage in weak businesses' and consumers' sentiments. The score of its long-term rating is 72.8. In fact, Taiwan mainly depends on exports from electronics industry.

The short-term score for South Korea is 74.0. It may highlight that its economy is affected by both regional and international markets, such financial crisis in 1998 and 2008. However, there are many emerging business opportunities for future development.

The short-term score of India is 67.1 since it has high foreign currency reserves and relatively low foreign debt stock. Its development is less favourable in the long-term economic outlook due to its fiscal deficits.

Thailand's short-term economic score is 75.6, with the principal shortage in the weak business. Its long-term score is 66.6. The main reason may be its high commodity imports and poor quality of government expenditure.

Pakistan has the short-term score of 43.1. Its primary weakness has a high current account deficit and thin foreign exchange reserves. The long-term score for Pakistan is 44.7 since it has low GDP per capital, a heavy reliance on commodity imports, and financial volatility.

The short-term score of Indonesia is 59.4. The country is constrained by the currency volatility and unstable 
banking systems. Its long-term score is 54.6 due to poor quality of government expenditure and banking sector.

Malaysia's short-term score is 70.4. Its government in 2009 announced the GDP achieved 9\%. Its long-term score is 72.8. However, the uncertainty of government expenditure may drag Malaysia's economy down in the long-term.

The short-term score for the Philippines is 65.8 due to government support. The long-term risk is less favourable at the score of 52.4 because it is lack of economic support from other developed countries.

Vietnam has the short-term score is 43.8 due to deterioration of its fiscal situation. The chronic fiscal and current account deficits may offset the growth of economic risk. Its long-term score is 53.3 since it could be a strong contender of a quick economic expansion.

\begin{tabular}{|c|c|c|c|c|c|c|c|}
\hline \multicolumn{4}{|c|}{ Table 1: Economic risk ratings for the short-term period } & \multicolumn{4}{|c|}{ Table 2: Economic risk ratings for the long-term period } \\
\hline & S-T Economy & & Trend & & L-T Economy & Rank & Trend \\
\hline China & 92.1 & 1 & $=$ & Singapore & 78.6 & 1 & \\
\hline Singapore & 83.3 & 2 & + & China & 75.1 & 2 & \\
\hline Hong Kong & 79.8 & 3 & + & Australia & 74.9 & 3 & $=$ \\
\hline Thailand & 75.6 & 4 & $=$ & Hong Kong & 74.8 & 4 & + \\
\hline South Korea & 73.1 & $\begin{array}{l}4 \\
5\end{array}$ & + & Malaysia & 72.8 & 5 & $=$ \\
\hline Taiwan & 72.9 & 6 & $=$ & Taiwan & 72.8 & 6 & $=$ \\
\hline New Zealand & 70.6 & 7 & $=$ & South Korea & 70.7 & 7 & $=$ \\
\hline Malaysia & 70.4 & 8 & $=$ & New Zealand & 68.0 & 8 & $=$ \\
\hline India & 67.1 & 10 & - & Thailand & 66.6 & 9 & $=$ \\
\hline Philippines & 63.3 & 11 & $=$ & India & 60.5 & 11 & $=$ \\
\hline Australia & 61.3 & 12 & $=$ & Indonesia & 54.6 & 12 & $=$ \\
\hline Indonesia & 59.4 & 13 & $=$ & Bangladesh & 53.3 & 13 & $=$ \\
\hline Laos & 56.3 & 15 & $=$ & Vietnam & 53.1 & 14 & $=$ \\
\hline Bangladesh & 54.8 & 16 & + & $\begin{array}{l}\text { Philippines } \\
\text { Sil }\end{array}$ & 51.2 & 15 & $=$ \\
\hline Sri Lanka & 45.0 & 17 & & $\begin{array}{l}\text { Sri Lanka } \\
\end{array}$ & 4.2 & ${ }_{17}^{16}$ & $=$ \\
\hline Vietnam & 43.8 & 18 & $=$ & $\begin{array}{l}\text { Laos } \\
\text { Pakisłan }\end{array}$ & $\begin{array}{l}4.1 \\
44.7-1\end{array}$ & ${ }_{18}^{11}$ & $=$ \\
\hline Pakistan & 43.1 & 19 & & $\begin{array}{l}\text { Pakistan } \\
\text { Mvanmar }\end{array}$ & ${ }_{344}^{44.1}$ & ${ }_{20}^{18}$ & $=$ \\
\hline Myanmar & 10.8 & 21 & $=$ & $\begin{array}{l}\text { Myyanmar } \\
\text { North Korea }\end{array}$ & & 20 & $\begin{array}{l}= \\
=\end{array}$ \\
\hline $\begin{array}{l}\text { North Korea } \\
\text { Regional average } 603\end{array}$ & Global averace 54.8 & 22 & $53 \stackrel{=}{=}$ & Regional average 58.7 & Global average 53.4 & Emerging Ma & ge 50.8 \\
\hline & & & & - & & & \\
\hline
\end{tabular}

\subsection{SWOT analysis for the economic outlook}

\section{Singapore}

\section{Strengths}

- Stable and credible exchange rate to offset inflationary pressures

- Good current account surplus remaining at about $15 \%$ of its GDP

\section{Weaknesses}

- The trade-dependent economy mainly relying on the demand of electronic products

- Long-term economic problems, such as competition from other low-labour cost countries

\section{Opportunities}

- Identifying new areas: biomedical sciences, and medical \& financial services

- Expanding its investments in different global projects

\section{Threats}

- $\quad$ Competing with other low-wage economic countries, such as China and India

\section{China}

\section{Strengths}

- Fastest-growing major economy in the world

- A massive trade surplus and huge foreign exchange reserves

- Continue to reform its economy

\section{Weaknesses}

- The imbalance economic growth and environmental degradation

- Dependency on exports to boost the economic growth

- Lack of effective communication between governments and local businesses

Opportunities

- Increasing domestic consumption to stimulate its economic growth 
- Ongoing urbanization as a major driver to emerge new cities

- Developing more Chinese global firms

\section{Threats}

- Job losses in China's export sector and the increase of social instability

- High food price inflation

\section{Japan}

\section{Strengths}

- The second largest economy in the globe

- Developed high-tech manufacturing and services sectors

\section{Weaknesses}

- Hampered economy controlled by special interest groups

- Shrunk population and the highest proportion of citizens aged over 65

\section{Opportunities}

- More benefits from emerging demand from other Asian countries, such as China and India

- The policies for the long-term economic reform launched by the government

Threats

- Mainly depend on exports as a driver of its growth

- $\quad$ Costs of debt (25 percent of the annual budget)

India

Strengths

- $\quad$ Larger domestic markets

- Inexpensive supply

- Booming exports of IT-enabled services

Weaknesses

- $\quad$ Remaining a very poor country although fast economic growth

- Inefficient agriculture industry

- Chronic trade and fiscal deficits

\section{Opportunities}

- Continuing to drive demand for new goods and services

- Implementing some policies for the tax reforms

Threats

- The price-driven inflation caused by the problem of relying on oil imports.

- Environmental issues

- Lack of ability of sustainable growth

\section{Thailand}

\section{Strengths}

- Good economic performance

- The vulnerability of cash outflows reduction

Weaknesses

- Weak consumer sentiment

- Small size of skilled workers

\section{Opportunities}

- Emerging more large-scale infrastructure projects

- Economic recovery due to political issues resolved

Threats

- Volatile prices for key export goods 
- Continued political turmoil damaging the attractiveness of Thailand to foreign investors

Taiwan

Strengths

- The advanced high-tech industry

- High foreign exchange reserves

Weaknesses

- Challenges and opportunities from Mainland of China

- Highly dependent on external demand markets

Opportunities

- Improving business opportunities for many industries: tourism, banking, and shipping

- Improve Cross-Strait relationships with Mainland of China leading to have more business opportunities for Taiwanese firms

Threats

- The increase of its trade growth depending upon the growth of Mainland of China's economy

\section{Pakistan}

Strengths

- Ongoing economic structural reform

- Improving purchasing power of citizens

Weaknesses

- High fiscal deficits

- Poor population although fast economic growth

Opportunities

- Increasing rate of urbanization

- Trade growth due to close relationships with China

Threats

- Political issues significantly affecting the economic reform processes

\section{Indonesia}

Strengths

- Good strategic location, with the major East-West trade routes

- Low-cost labour resources

Weaknesses

- Increasing joblessness in the country

- Substandard physical infrastructure

\section{Opportunities}

- Attracting more foreign investment by strengthening its business environment

Threats

- The economy influenced by the sudden capital outflow at times of risk aversion

\section{Malaysia}

\section{Strengths}

- Transforming itself from a commodities-dependent economy into a major source for electronics and computer parts

- The world's largest producer of rubber, pepper, and tropical hardwoods

Weaknesses

- A burden of Malaysia's economic openness due to degree of international market change 


\section{Opportunities}

- The economic growth from private sectors

- The advantage of positioning a financial hub over the medium-term strategy

Threats

- Higher salaries compared to China and India

- $\quad$ Relying on migrant labour for low-skills jobs as a potential threat affecting the long-term economic stability

\section{The Philippines}

\section{Strengths}

- Private consumption as a major driver of economic growth

- Remittances are a key resource of national income

Weaknesses

- $\quad$ More expenditure on interest payments for borrowings

- High unemployment rate

\section{Opportunities}

- $\quad$ Easy to reduce pressure on national fiscal account

- Outsourcing of labour leading to more opportunities for foreign exchange

Threats

- The export industry influenced by the international markets

\section{South Korea}

\section{Strengths}

- Many world-class firms in the production of everything from mobile phones to chips.

- $\quad$ Free trade agreement with the European Union

Weaknesses

- The economic development affected by strikes due to a long history of labour militancy

Opportunities

- More opportunities for emerging high technology and biotechnology

- Seeking to boost the financial industry as one of main drivers to stimulate its economic growth

Threats

- Financial stability influenced by high level of external debt

\section{Vietnam}

Strengths

- A fast-growing country (GDP growth is 7.6\% between 2000 and 2007.)

- Lower poverty rate, from 58\% in 1993 to $20 \%$ in 2004 .

\section{Weaknesses}

- High fiscal deficits

- Weak incentives to improve quality of exports and inflationary pressure from high import costs

Opportunities

- $\quad$ Easy to access foreign markets due to a member of the World Trade Organisation (WTO)

- More business opportunities because of the effective economic reform

- The economic growth by expanding urbanization

Threats

- A lack of confidence from foreign investors due to the failure of dealing with inflationary pressure The political reform influenced by the instable macroeconomic environment. 


\subsection{Business environment}

This section mainly focuses on the business environment of the Asian countries. The table 3 shows the business environment risk ratings and the level of attractiveness of the countries for business investors. The higher scores represent that these countries have more stable business environment. Based on information of infrastructure and market orientation, BMI (2010) forecast future trends of business environment for the Asian countries.

Interestingly, all countries' trends remain the same. The regional and global average is 51.5 and 50.5 respectively. Singapore has the top position in Asia. Its rating reflects that the government continues to attract more foreign investment into Singapore. With having strong business fundamentals, Singapore should be in a good competitive position in the future.

China has a number of crucial obstacles for foreign investors wishing to do business in the country although it has a huge supply of cheap labour and a fast growing economy. Bureaucracy and legal framework become major concerns to China's foreign investment attraction.

The business environment rating score for Taiwan is 65.2. Cross-trait relations with Mainland of China will help Taiwan transform itself into a key region of logistics and financial hub. It could take market shares from competitors such as Hong Kong and Singapore.

The business environment rating for South Korea is 73.4. Its business environment should obtain a significant boost from the government's deregulation drive. It also has one of the most effective communication systems in the region. Its institutional framework could be a main challenge for South Korea's business environment.

The business rating score for India is 39.8. India has the high corporate tax rate and poor structure of law enforcement. The physical infrastructure is seen as a key weakness for India when compared to China and other countries. Its trade barriers aim at protecting domestic manufacturers.

Thailand has a score of 59.5 in business environment ratings. Thailand's business environment faces two primary challenges: the need to improve its market mechanism and the government's perceived inability to manage intellectual property rights (IPR). Its planned infrastructure over the next few years should help the country's businesses. The rating would be higher than the current score.

Pakistan has a score of 37.7 in business environment ratings. The main weakness of Pakistan is the poor performance in its physical infrastructure and political institution. An inefficient legal framework, weak rule of law and political corruption are the key obstacles for its business development.

Indonesia's business environment rating is 40.2. The underinvestment in physical infrastructure and political corruption remain the crucial obstacles to improving business environment. The recent transition to democracy has significantly improved the long-term prospects for doing business in Indonesia.

The business environment rating for Malaysia is 61.5. Several economic reforms make the country be more attractive for foreign investors. The primary issue for Malaysia is political corruption. A lack of transparency in biding is another issue for business environment development.

The Philippines' business environment rating is 45.0. Its main issue is underinvestment in the nation's infrastructure, while corruption remains a big problem in the political institutions. The business environment rating is supported by the Philippines' relative openness to trade and investment.

Vietnam has a score of 42.0 in business environment ratings. The physical infrastructure of the country is poor compared to other peer nations. A planned economy still present in many government bodies although the government plans to develop economic reforms. 


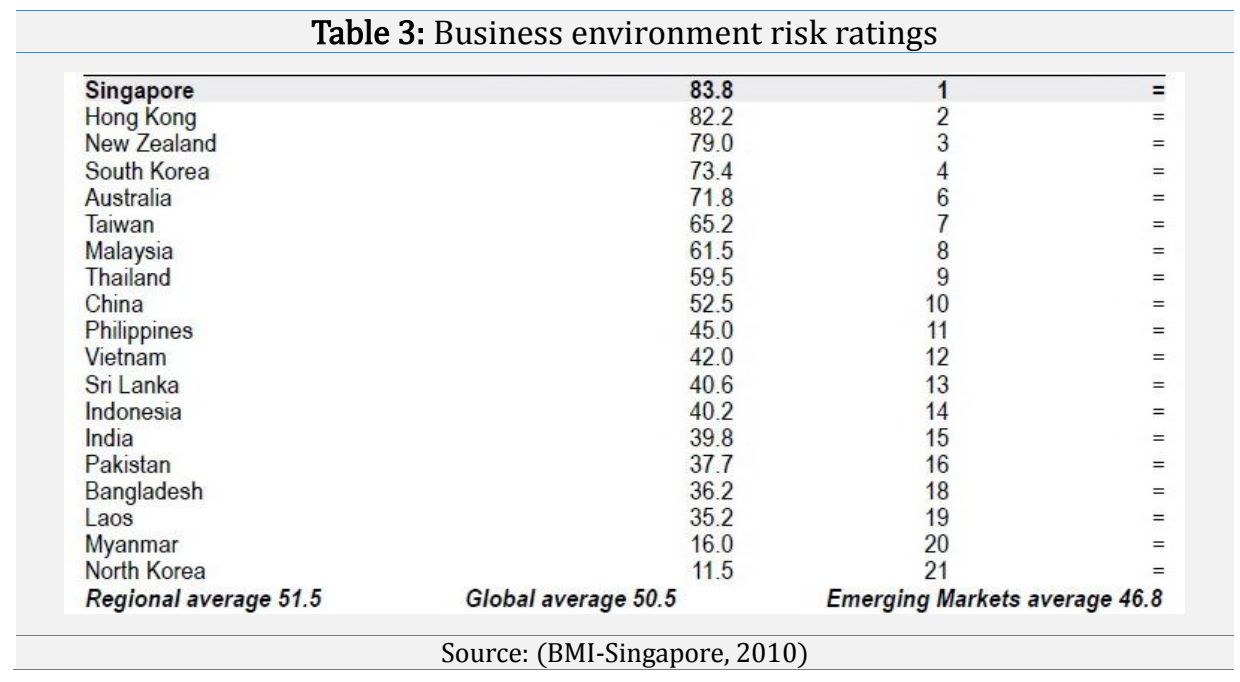

\subsection{SWOT analysis for business environment}

\section{Singapore}

\section{Strengths}

- The least corrupted country in Asia

- Rareness of labour protests

Weaknesses

- Political sensitive issues

- Limitation of distribution centres

Opportunities

- Having 19 bilateral free trade agreements

- The best business operating environments in Asia

Threats

- Potential risk of a terrorist attack due to identified a target by Islamist militants from neighbouring Indonesia and other places

\section{China}

Strengths

- Ongoing open up various industries to attract more foreign investments

- Large supply of cheap labour

\section{Weaknesses}

- The poor protection of intellectual property in China

- Weak corporate governance in the state-own enterprises

Opportunities

- Ongoing the development of urbanization and physical infrastructure to mark more attractiveness for foreign investors

- More protection to private sectors

Threats

- Block to take over crucial national assets

India

Strengths

- One of biggest recipients of foreign direct investment

- Inexpensive and skilled English-speaking labour force 
Weaknesses

- Lower literacy rates compared to other peer nations

- Poor physical infrastructure

- Poor to protect intellectual property rights

Opportunities

- Ongoing infrastructure projects ranging from roads, railways, and airports

- Enhancing the competitiveness of local industry by deregulation

Threats

- Growing challenges from other Asian countries

- Low attractiveness for foreign direct investment compared to China

\section{Thailand}

Strengths

- A moderate free economic region in Asia

Weaknesses

- Poor protection of intellectual property

- Hard to attract foreign direct investment due to the weak legal framework

\section{Opportunities}

- Large supply of labour-intensive products, such as petrochemicals and food processing

- Efforts to protect intellectual property in order to increase the country's attractiveness

Threats

- Political corruption as a primary obstacle to do business in Malaysia

\section{Taiwan}

\section{Strengths}

- Having leading the high-tech industry in Asia

- High-quality of physical infrastructure and well-educated labour force

Weaknesses

- High tax levels compared to other peer regions

- An increase of land and labour costs compared to Mainland of China

Opportunities

- A free economic region in Asia

- An increase of domestic demand in order to attract more foreign investments

Threats

- Information leakage as a key issue for Taiwanese high-tech firms

\section{Pakistan}

\section{Strengths}

- One hundred percent foreign equity allowed in the manufacturing industry

- Reducing tariff barriers by ongoing economic reforms

Weaknesses

- Political corruption as a primary concern for the foreign investors

- Weak intellectual property rights

\section{Opportunities}

- Encourage to sell off the state-owned enterprises in order to increase the rate of private sectors

Threats

- A high-risk destination for the foreign investors due to unstable business environment 


\section{Indonesia}

Strengths

- More business opportunities for domestic markets

- Low tariffs for import and export goods

Weaknesses

- Political corruption as a primary issue

- Excessive bureaucracy as an obstacle to do business in the country

Opportunities

- Improving the business environment in order to boost investor interest in Indonesia

- Amending its debt and banking regulations in order to increase domestic demand

Threats

- $\quad$ Some legal problems and obstacles due to opportunistic behaviours by foreign investors

\section{Malaysia}

\section{Strengths}

- Improving the standards of corporate governance in Malaysia.

- Low tariffs in order to attract more foreign firms

Weaknesses

- Need to establish well relationships with the local government

- A lack of flexible price mechanism in domestic markets

Opportunities

- The opportunity to invest in Malaysian state assets

- A strong possibility of bank consolidation in Malaysia

Threats

- The threat of terrorism around the shipping lanes in Malaysia

- A potential threat from raising China's economy in the race for foreign investments

\section{The Philippines}

\section{Strengths}

- Low-cost and educated English-speaking workforce

- A member of the association of Southeast Asian Nations (ASEAN)

Weaknesses

- The political and security issues to block to do business in the country

- Poor physical infrastructure as a key issue for foreign investors

\section{Opportunities}

- The opportunity to offer outsourcing service to North America and Western Europe

Threats

- A major threat from other peer nations

- Political corruption as a primary concern for foreign investors

\section{South Korea}

Strengths

- Improved the standards of corporate governance

- Good transport infrastructure

- High educated workforce

Weaknesses

- Union power as a obstacle to do business in South Korea

- High power of economic nationalism to influence the levels of foreign takeovers 


\section{Opportunities}

- Having more emerging business opportunities

- Using North's cheaper labour force through joint economic projects

Threats

- The nuclear threat of North Korea as a major security threat to South Korea

\section{Vietnam}

\section{Strengths}

- Many high-educated and low-cost workforce to attract more foreign investors

- A good physical location closed to China and Southeast Asia

- A good place for foreign firms to export and import goods from the rest of Asia

\section{Weaknesses}

- Weak physical infrastructure

- One of the world's most corrupt countries

\section{Opportunities}

- Increasingly attracting investments from other peer nations

- An opportunity for state-owned enterprises to transfer of high-tech skills and know-how.

\section{Threats}

- The general threat of American protectionism to influence export goods

- A potential threat of the unemployed labour to affect the development of its economy for an indefinite period

According to the analysis of the economic trend and business environment, the figure 1 shows the stability evaluation for the Asian countries in a $2 \times 2$ matrix. The economic trend and business environment as two major factors evaluate the stability of the Asian countries for the short-term and long-term periods. For short-term period, Singapore has the most stable position compared with other Asian countries. It is followed by South Korea, Taiwan, Malaysia, Thailand, and China are more stable. Pakistan is the least stable country.

For long-term period, Singapore still has the most stable position compared with those countries. Although Thailand is in the stable section, it is less stable than four countries, South Korea, Taiwan, Malaysia, and China. Pakistan is again the least stable country for the long-term period. We suggest that the company should consider looking for suppliers who are from those stable countries since they have good physical infrastructure, stable business environment, and reliable suppliers. For those of less stable countries, the company should have sufficient abilities to overcome the current and potential risks although those countries have their own advantages.

Figure 1: Stability evaluation for the Asian countries

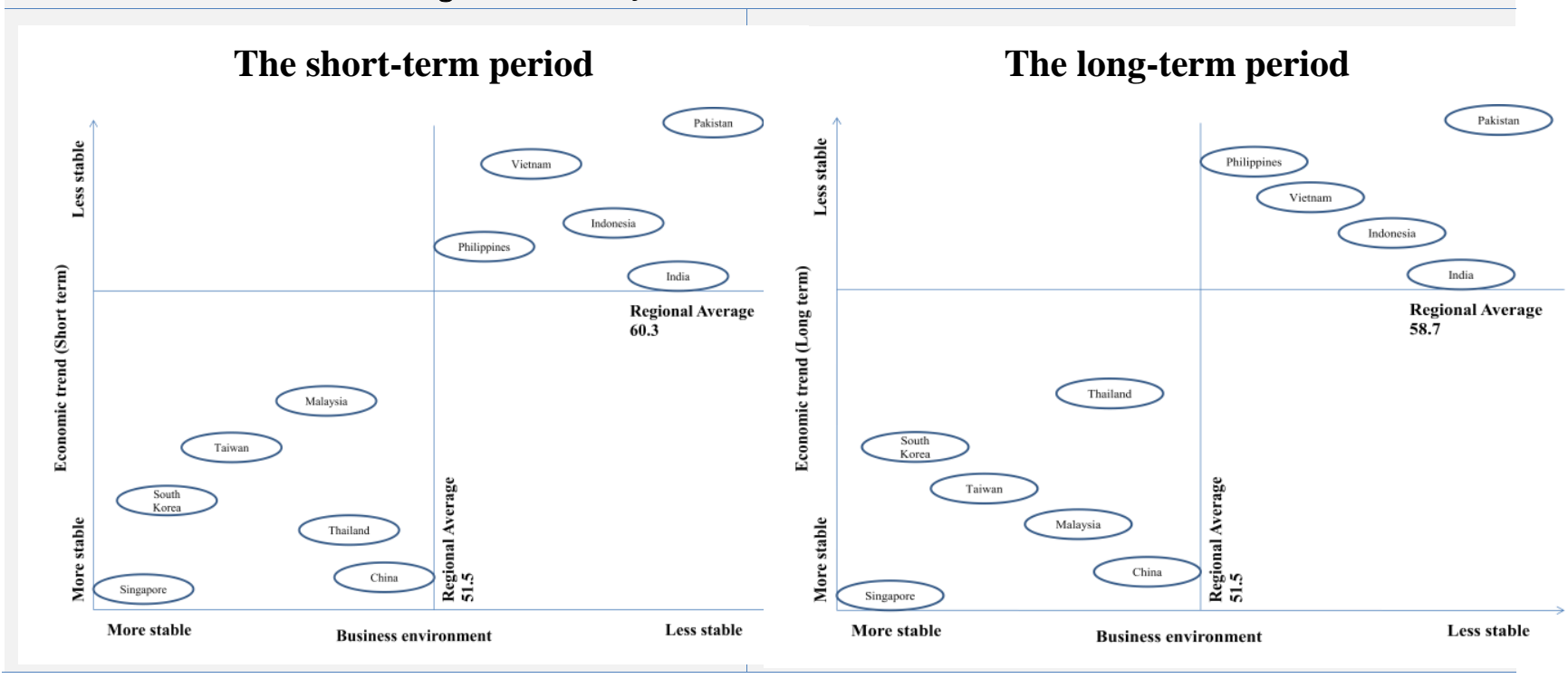




\subsection{Key industries}

\subsection{Describing key industries for the Asian countries}

The section will identify the key industries and most popular export commodities (survey conducted by Alibaba.com) for the Asian countries. The popular commodities mean that they are highly exported to other nations.

\section{Singapore}

Singapore's consumer electronic market, including computing devices, mobile handsets and video, audio and gaming products, was forecast to be worth about US \$3.2bn in 2009 (BMI-Singapore, 2010). Singapore remains an important hub for R\&D of electronic products and electronic manufacturing services. Local manufacturing includes four segments: computer peripherals, data storage, consumer electronics, and other electronics modules and components. The following lists some popular types of export goods ranked by Alibaba.com, which is one of the world largest business-to-business e-commerce firms. For each type of product, alternative manufacturers/ distributors are listed as well.

- Gifts (Jasskee Ltd, St. Neir Creations)

- Cards (Amir Ltd, SWEE Huat Plastic Company)

- Fashion (Cruise International Holdings, Athena's Closet Marketing Ltd)

- Computers (EURO Dynamic marketing PTE Ltd, Bymacht Ltd)

- $\quad$ MP3s (C \& K Marketing PTE Ltd, Jasskee Ltd)

- Memory Cards (Zhongvua Import \& Export Trading, Alstron Ltd)

\section{China}

The total retail sales are expected to increase by 43\%, growing from US \$1.54trn in 2008 to US $\$ 2.54$ trn by 2013 (BMI-China, 2010). For instance, pharmaceuticals may grow from US \$8.50bn to US \$16.68bn (BMI-China, 2010). Sales of consumer electronic products increase US \$111.36bn in 2008 to US\$160.58bn in 2013 (BMI-China, 2010). Moreover, sales of clothing and textiles estimate US\$277.29bn in 2008 (BMI-China, 2010).

The full range of products can be purchased in China. The company has a purchasing centre in Shanghai, so this report is not including the alternative Chinese manufacturers and distributors.

\section{Japan}

Japan's grocery industry is still fairly fragmented, with supermarkets, hypermarkets, discount and convenience stores. Many grocery wholesalers operate loss-making and price-cutting strategies during the economic downturn. The country's leading operators are AEON, Seven \& iHoldings, Daiei, Seiyu and Lawson. Some export goods identified by Alibaba.com are:

- Makeup products (Dukes International Co. Ltd)

- Handmade paintings (ETOH Trade)

- Micro Screw driver (Matsumoto Co. Ltd)

- Car oil (Newest INC)

- Mail boxes (Yamaguchi Manufacture Co. Ltd)

- $\quad$ Baby Diapers (Toyota, Co. Ltd)

\section{India}

India retail sales grow from US\$357bn in 2008 to US\$711bn by 2013. Domestic retailers, such as Reliance retail and Pantaloon retail, will continue growing their store network. Consumer electronic sales were at US\$26.56bn in 2008. India has most popular export products from the garment industry. Some key manufacturers and wholesalers for different industries are:

- Photo Frames (Cine City Co. Ltd)

- Apparels (Enkay Exports Co. Ltd)

- Industry Garments (Trimurti Co. Ltd)

- Suede Leather Cord (Shivam Co. Ltd)

\section{Thailand}

Thailand's consumer electronic market will grow to US\$8.2bn by 2013. Manufacturing sub-sectors for electronics is important in Southeast Asia. In 2009, the government announced to cut off tariffs on some components for the electronic industry in order to help this industry survive the current economic downturn.

The hand-craft industry also produces some products for the export. The list below is the popular products from Thailand: 
- $\quad$ Art (Textile Development Co. Ltd, Laiya Co. Ltd)

- Decoration (KTR Décor, BIZ Co. Ltd)

- Bags (Nanfa Manufacturing Co. Ltd, KTR Décor)

- Cans (Mahachoke Mahachai Trading Co. Ltd, Smile and Goodwill Co. Ltd)

- Candles (Nine Natural Trading Co. Ltd, SIAM Quality industries Co. Ltd)

- Fabrics (ARC Design Co. Ltd, BSK Textiles Co. Ltd)

- Leathers (PP Premium Goods LP, Platinum Bangkok Co. Ltd)

- Containers (Yuen Yong Enterprise )

- Foods (United Jivan Co. Ltd)

\section{Taiwan}

Taiwan has a significant advantage for the high-tech products. The range of products includes LED, batteries, light, displays, and so forth. Some key manufacturers and wholesalers are:

- Auto (Dutech Industrial Co. Ltd, Shinest Industries INC)

- Controller (Chia Wei Electric Co. Ltd, Citysmart Co. Ltd)

- LED (Win Strong Electronics Co. Ltd, Kendu International Inc.)

- Batteries (Buranaby International Technology Corp, Wansglory Co. Ltd)

- Custom Designs (Tech Arts International Co. Ltd, Mictech Security Co. Ltd)

- Light (Jenbo Lighting International Co. Ltd, High Tech Global Group)

- Displays (Lonchi Technology Trade Co. Ltd, Tai Mei Acrylic Co. Ltd)

- Cards (Power TAC Enterprise Ltd, Kguard Security Co. Ltd)

- LCD (Eago Technology Co. Ltd, Hungtec Technology Co. Ltd)

- Memories (AE Tech Co. Ltd, O'Top Technology Co. Ltd)

- Toys (Calinnesco. Ltd)

\section{Pakistan}

The food and drink industry is one of fast growth industries in Pakistan. BMI (2010) points out that Pakistan is among the highest per capita tea consumers in the world. It does not indicate that the industry slow down anytime. The value of Soft drinks sales increase by 39.8\%. Some export popular products list below:

- Balls (Uni Pro Manufacturing Company, Dar \& Sons International Co. Ltd)

- Garments (Hussain Leather Industries, Kadia International Company)

- Leather Gloves (Father Son Industry, Kartrace Safety International)

- Boxing (M.A. International, Karam industries)

- Gloves (Murtaza Group, Gelal INC.)

- $\quad$ Leather Motorbike Jacket (Leather Hills Co. Ltd)

- Cotton (Sindh Argo Co. Ltd, South Asian Sourcing LTD)

- $\quad$ Fabrics (Worldover Enterprises Ltd, B-TEX Exports)

- Jackets (Beauty \& Beauty Worldwide, Faport International)

\section{Indonesia}

Due to the low-cost labour resource, the labour-intensive manufacturing is quite common in Indonesia. Some popular export products are shown below:

- Copy paper (Tiga Sakti Export Co. Ltd)

- Furniture (Multi Buana Co. Ltd)

- Kayak (Mitra Kayak and Canoe Co. Ltd)

- Guitar (Bina Indo Pratama Co. Ltd)

- Tables (Dewan Koperasi Co. Ltd)

- Sandals (Megan Kencana Co. Ltd)

- $\quad$ Drums (Bali Treasures Co. Ltd)

\section{Malaysia}

Malaysia is a small to medium-sized textiles and clothing manufacturer. Its total sales were US\$1.78bn in 2008. Export growth will be averaged $6.7 \%$ in the five years to 2008 . The key challenge is maintaining competitiveness in the falling global demand. The margins of textiles industry will be squeezed from $8.4 \%$ in 2009 to $2.4 \%$ in 2010 . Some export products list below:

- Chairs (Jetexim Business Co. Ltd)

- A4 Papers (Erapoly Co. Ltd)

- Rubber Gloves (Rubberex Markeing Co. Ltd)

- Palm Oil (Big Titans Co. Ltd)

- Flooring (Amvt Co. Ltd)

- TIW Rubber (T-angle SDH Co. Ltd) 
- $\quad$ Shoes (Hup Kung Enterprises)

- Camping light (Net Kami Electronic Co. Ltd)

- Toys (Wisness Marketing Co. Ltd)

\section{The Philippines}

The Philippines has many labour-intensive manufacturers. Bags, gifts, baskets, fashion accessories are most prevalent products in the Philippines. Some primary manufacturers and wholesalers are shown below:

- Bags (APN Crafts Enterprise, Melawares Manufacturing Co. Ltd)

- Gifts (Debaro Export Co. Ltd, Stavellan INC.)

- Crafts Gifts (Zuleika International Co. Ltd, Shekinah Arts \& Krafts Co. Ltd)

- Baskets (Debaro Export Co. Ltd, Melawares Co. Ltd)

- Candles (Doc's Candles Co. Ltd)

- Fashion Accessories (Larone Crafts Co. Ltd, Gellyle Fashion Accessories Co. Ltd)

- $\quad$ Furniture (BMM Trading Co. Ltd, T \& H Shop fitters Corp)

- $\quad$ Dried fruits (Comet Enterprise Co. Ltd)

- Toys (JS Philippines global Co. Ltd)

\section{South Korea}

There are many types of export products in South Korea. The electronic industry is quite popular in the country, such as Samsung and LG. The food and drink industry is also key industry for the export. The total sales of the industry will increase by $26.3 \%$ to reach KRW $77,933 \mathrm{bn}$ by 2013 . Some popular export products are shown below:

- Ginseng Tilon (Hanil Ginseng Co. Ltd)

- Vitamin Balls (Biocera Co. Ltd)

- Green Tea (Sahm Yook Foods Co. Ltd)

- V-neck T-shirt (SH Trading Co. Ltd)

- Crystal Kitchen Light (Dongbang Hitec Co. Ltd)

- Flyfish Banana Boat (Woosung I.B. Co. Ltd)

- Optical lens (I \& G Optics Co. Ltd)

- Organic pesticides (Ecowin Co. Ltd)

- Toys (Aurora World Co. Ltd)

\section{Vietnam}

Vietnam mainly exported crops, rice and coffee in 2009. Vietnam's coffee crop is estimated to have grown 7.3\% yo-y to $19.67 \mathrm{mn} 60 \mathrm{~kg}$ bags. Vietnam's key agricultural industry has been developed significantly. Take rice for an example. The expected production will grow by $15.0 \%$ from the 2009 level to $28.10 \mathrm{mn}$. Other types of popular export products are:

- Furniture (B.M.C Manufacturing and Trading Co. Ltd)

- Bamboo basket (Thang Long Export Import Co. Ltd)

- $\quad$ Flower Vase (Vinh Co. Ltd)

- Plastic bag (Plastic Technology Co. Ltd)

- Seagrass Handbag (Bao ANH Co. Ltd)

- Shoes (First Alliance Co. Ltd)

- TCW Sofa (Tam Long Craft Co. Ltd)

- Cotton Yarn (Dai Cuong Group Co. Ltd)

\subsection{Niche market VS mass market}

A niche market is the segment that focuses on special requirements. It requires the feature of a specific product to meet the particular market need, such as price range, production quality and the demographics impacted.

The mass market is the group of customers who take the overwhelming mass for common products. Those group members of their desires towards a certain products may be completely different from other group of customers. 
Figure 2: Mass and niche markets for the popular products
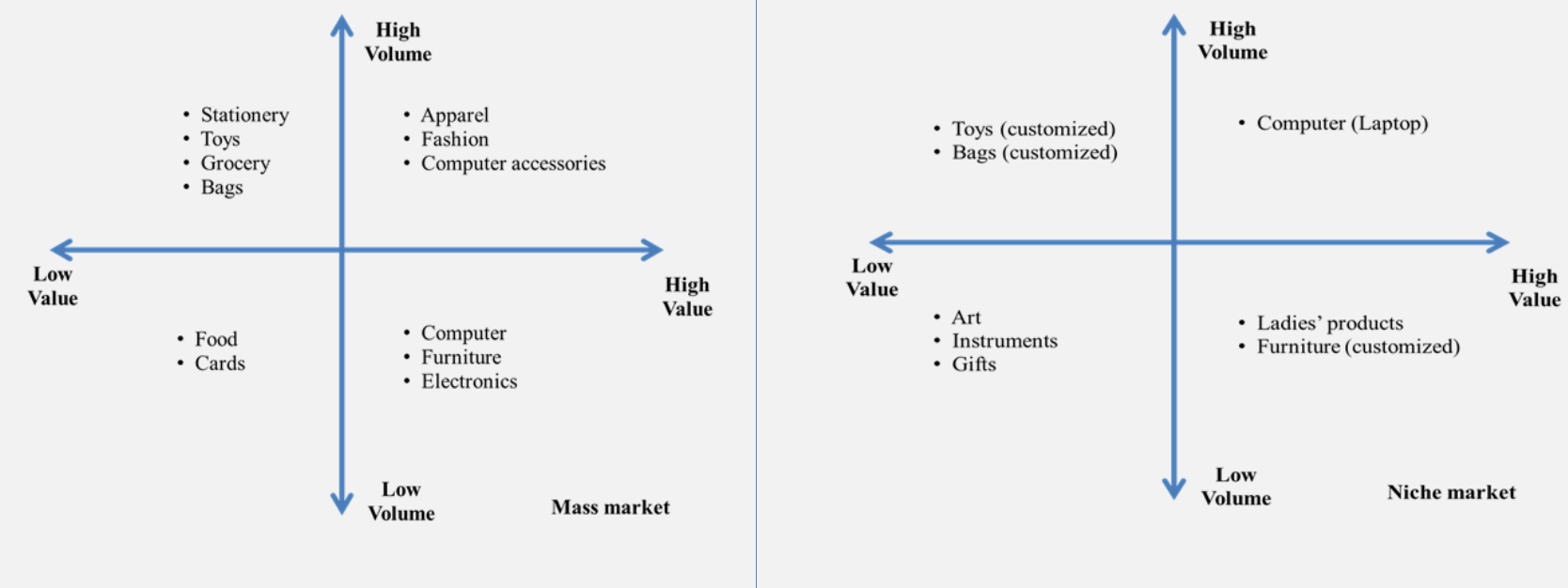

Table 4: Summary of popular export products

\begin{tabular}{|c|c|c|c|c|c|c|c|c|c|c|c|c|c|c|}
\hline $\begin{array}{l}\text { Products } \\
\text { Countries }\end{array}$ & Gifts & Cards & $\begin{array}{c}\text { Apparel } \\
\& \\
\text { Fashion }\end{array}$ & $\begin{array}{l}\text { Computer \& } \\
\text { accessories }\end{array}$ & $\begin{array}{l}\text { Ladies' } \\
\text { products }\end{array}$ & Grocery & Art & Bags & Furniture & Instrument & Stationary & Food & Electronics & Toys \\
\hline Singapore & $\checkmark$ & $\checkmark$ & $\checkmark$ & $\checkmark$ & & & & & & & & & $\checkmark$ & \\
\hline China & $\checkmark$ & $\checkmark$ & $\checkmark$ & $\checkmark$ & $\checkmark$ & $\checkmark$ & $\checkmark$ & $\checkmark$ & $\checkmark$ & $\checkmark$ & $\checkmark$ & $\checkmark$ & $\checkmark$ & $\checkmark$ \\
\hline Japan & & & $\checkmark$ & & $\checkmark$ & $\checkmark$ & & & & $\checkmark$ & & & $\checkmark$ & \\
\hline India & & & $\checkmark$ & $\checkmark$ & & $\checkmark$ & & & & & & & & \\
\hline Thailand & $\checkmark$ & & $\checkmark$ & & $\checkmark$ & $\checkmark$ & & $\checkmark$ & & & & $\checkmark$ & $\checkmark$ & \\
\hline Taiwan & & & & $\checkmark$ & & & & & & & & & $\checkmark$ & $\checkmark$ \\
\hline Pakistan & $\checkmark$ & & $\checkmark$ & & & & & & & & & & & \\
\hline Indonesia & & & & & & & & & $\checkmark$ & $\checkmark$ & $\checkmark$ & & & \\
\hline Malaysia & & & $\checkmark$ & & & & & & & & $\checkmark$ & & $\checkmark$ & $\checkmark$ \\
\hline Philippines & $\checkmark$ & & & & $\checkmark$ & $\checkmark$ & & & $\checkmark$ & & & $\checkmark$ & & $\checkmark$ \\
\hline South Korea & $\checkmark$ & $\checkmark$ & $\checkmark$ & & & $\checkmark$ & & & & & & & $\checkmark$ & $\checkmark$ \\
\hline Vietnam & & & $\checkmark$ & & $\checkmark$ & $\checkmark$ & & & $\checkmark$ & $\checkmark$ & & & & \\
\hline
\end{tabular}

Based on table 4, these products can be classified into the mass and niche markets. Product volumes and values are two important factors to evaluate each category for a particular product. The global sourcing manager for the Warehouse has helped prepare a $2 \times 2$ matrix addressing the value and volume dimensions relevant to the Warehouse shown in figure 2.

In a mass market, some products, such as apparel \& fashion, and computer accessories, have high volume and value, so the company should have a priority for purchasing those products. The products that have high value and low volume, such as computer, furniture, and electronics, should have the next priority for the company.

In a niche market, the company may need to satisfy particular small groups of customers. For instance, some computers are designed specifically for business professionals, so they may need to have top-of-the-line configurations in order to satisfy the customers. The company also considers purchasing other high value products for a niche market, like furniture. Some customers may have specific requirements for the furniture, so the company may satisfy their needs.

There is high competition in the mass market because its entry barriers are quite low. The company also needs to consider turnover rate for new products, such as computers and electronics because their life cycles are rather short. Normally, it will need to change new products after a couple of months or one year. The company does not need to store high inventories for those high value products in this market. The company may need the mediumterm (three months or a half year) product availability for the common products to meet future demand, such as grocery, stationery, toys, cards, and so forth.

The company tries to provide customized and differentiated services for the specific customers in the niche market. Some clients may want to pay extra for such service. The company should focus on improving its customer service 
levels in order to satisfy the customers' needs. According to their different specific requirements, the pull strategy may be suitable for the company in this market. The company does not have the high capacity to store the finished products. The company can send a request for producing and shipping the products once a customer order has been placed. The overall lead time should be suit for the client needs. It requires similar specification and certain quantity for the products. Otherwise, the company may lose the profit margins.

\begin{tabular}{|l|c|}
\hline \multicolumn{2}{|c|}{ Table 5: Product procurement opportunities from the Asian countries } \\
\hline Countries & Product categories \\
\hline Singapore & 1 \\
\hline China & 14 \\
\hline Japan & 3 \\
\hline India & 0 \\
\hline Thailand & 4 \\
\hline Taiwan & 3 \\
\hline Pakistan & 0 \\
\hline Indonesia & 3 \\
\hline Malaysia & 3 \\
\hline Philippines & 3 \\
\hline South Korea & 3 \\
\hline Vietnam & 1 \\
\hline Countries & 1 \\
\hline Singapore & 14 \\
\hline China & 3 \\
\hline Japan & 0 \\
\hline India & 4 \\
\hline Thailand & 3 \\
\hline Taiwan & 0 \\
\hline Pakistan & 3 \\
\hline Indonesia & 3 \\
\hline Malaysia & 3 \\
\hline Philippines & 3 \\
\hline South Korea & 1 \\
\hline Vietnam & \\
\hline & Product categories \\
\hline
\end{tabular}

According to the survey conducted by Alibaba (Alibaba.com, 2010), table 6 (below) shows the most popular purchasing destinations in Asia. It may be preferable to purchase the high volume and high value products in China, Thailand, Malaysia, Taiwan, and Singapore. Those countries are the most favourable purchasing destinations based on the buyer's preference and purchasing experience. Southeast Asian countries are the favourable purchasing destinations for the common products (low value). These countries have many advantages, such as low labour costs and mature technology.

If the company wants to put more efforts on the niche market, it needs to consider all relevant variables together, like supplier's competence and capability, quality, lead time, and so on. Most buyers prefer to purchase the products in Eastern Asian countries since the physical infrastructure of this region has been growing fast. China, Japan and South Korea have become three primary economic entities in Asia. These countries have highly reliable and trustworthy suppliers. The competence and capacity of their suppliers can meet the purchasing goal for the company.

Table 5 shows product procurement opportunities from the Asian countries. China is the most favourable purchasing destination compared to other peer nations. However, the scores for Japan, Thailand, Taiwan, Indonesia, Malaysia, the Philippines, and South Korea are quite similar. The company needs to consider other variables when determining the purchasing destinations, such as physical infrastructure, supplier reliability, political issue, labour cost, and so forth. The final purchasing decision could rely on the company's preference and the country's characteristics for particular products. 


\begin{tabular}{|c|c|c|c|c|c|c|c|c|c|c|c|c|c|c|}
\hline \multicolumn{15}{|c|}{ Table 6: Favorable purchasing destinations in Asia } \\
\hline Products & Gifts & Cards & $\begin{array}{c}\text { Apparel } \\
\& \\
\text { Fashion }\end{array}$ & $\begin{array}{c}\text { Computer \& } \\
\text { accessories }\end{array}$ & $\begin{array}{l}\text { Ladies' } \\
\text { products }\end{array}$ & Grocery & Art & Bags & Furniture & Instrument & Stationary & Food & Electronics & Toys \\
\hline Countries & & & & & & & & & & & & & & \\
\hline Singapore & & & & $\checkmark$ & & & & & & & & & & \\
\hline China & $\checkmark$ & $\checkmark$ & $\checkmark$ & $\checkmark$ & $\checkmark$ & $\checkmark$ & $\checkmark$ & $\checkmark$ & $\checkmark$ & $\checkmark$ & $\checkmark$ & $\checkmark$ & $\checkmark$ & $\checkmark$ \\
\hline Japan & & & & & $\checkmark$ & & & & & $\checkmark$ & & & $\checkmark$ & \\
\hline \multicolumn{15}{|l|}{ India } \\
\hline Thailand & & & $\checkmark$ & & $\checkmark$ & $\checkmark$ & & $\checkmark$ & & & & $\checkmark$ & & \\
\hline Taiwan & & & & $\checkmark$ & & & & & & & & & $\checkmark$ & $\checkmark$ \\
\hline \multicolumn{15}{|l|}{ Pakistan } \\
\hline Indonesia & & & & & & & & & $\checkmark$ & $\checkmark$ & $\checkmark$ & & & \\
\hline Malaysia & & & $\checkmark$ & & & & & & & & $\checkmark$ & & & $\checkmark$ \\
\hline Philippines & $\checkmark$ & & & & & & & & $\checkmark$ & & & $\checkmark$ & & \\
\hline South Korea & $\checkmark$ & $\checkmark$ & & & & & & & & & & & $\checkmark$ & \\
\hline Vietnam & & & & & & $\checkmark$ & & & & & & & & \\
\hline
\end{tabular}

\subsection{Conclusion}

Based on the risk assessment of the economy and business environments, Singapore, South Korea, Taiwan, Malaysia, Thailand, and China are recognised as the more stable countries to source products and services from in contrast to the Philippines, Vietnam, Indonesia, India, and Pakistan. Singapore has a more stable environment with rare labour protests.

The primary weakness of Singapore is its reliance on the demand of electronic goods. China has become a fast major economy in the world, and continued to offer cheap labour. The weaknesses for China are the imbalance economic growth and weak corporate governance. The main strengths for Japan are its developed high-tech manufacturing and services industries.

The advantage of India is its inexpensive and skilled English-speaking labour force. Its weakness is lower literacy rates compared with other peer nations. Thailand has a moderate free economy in Asia and its vulnerability of cash outflows has been reduced. Taiwan is a leader in the high-tech industry in Asia, and has a high-quality physical infrastructure and well-educated workforce. High tax levels and labour costs are primary weaknesses for Taiwan. Pakistan tries to reduce tariff barriers through developing economic reforms, and its weaknesses are the widespread corruption and failing physical infrastructure. The strengths of Indonesia are the low-cost labour resource and non-tariff barriers to trade.

The political corruption is a primary issue for Indonesia. Malaysia is the world's largest producer of rubber, pepper, and tropical hardwoods, and it improves the standards of its corporate governance. The weakness of Malaysia is that foreign firms will always need to establish good relationships with the government. The primary strength for Philippines is a low-cost and educated English-speaking workforce, and the political and security concerns become major reasons of its weaknesses.

South Korea has the efficient corporate governance and high educated-workforce. Its weaknesses are economic nationalism and union power. Vietnam has a large, skilled and low-cost labour in order to attract more foreign investors. Its primary weakness is to suffer from the fiscal deficits.

The popular export products of these countries are quite different. The popular products for Singapore are gifts, cards, appeal \& fashion, computer \& accessories, and electronics. The popular products for Japan are ladies' products and households. Thailand has gifts, appeal \& Fashion, bags, and so forth. As a major purchasing destination, China can supply the full range of products. However, some other Asian countries may supply some cheaper products compared to China.

A further recommendation for the company is that the high volume and value products are preferable to be purchased in China, Thailand, Malaysia, Taiwan, and Singapore. Southeast Asian countries are favourable for the common products due to the low labour costs and mature technology. East Asian countries would be more favourable for the customised products. 


\section{References}

Business Monitor International. (2010). Business Forecast Report-Singapore. London: Richard Londesborough \& Jonathan Feroze.

Alibaba Websites. (2010). Retrieved Feburary 10, 2010, from www.alibaba.com 